\title{
A Pragmatic Analysis of Requests in Irish English and Russian
}

\author{
Martina Maria McCarthy \\ University College Cork \\ Martina.mccarthy@umail.ucc.ie
}

\begin{abstract}
This study focuses on contrastive pragmatics in the realization of the speech act of requests in Irish English and Russian in conversational and institutional settings. A quali-quantitative analysis was conducted to investigate how each language differs in realizing requests in each setting and to identify commonalities and differences between them. An original ten-question written discourse completion task (WDCT) was completed by 30 Irish English and 30 Russian native speakers, which generated data of 600 responses. Five units of analysis were coded, and descriptive statistics were used for comparison. Additionally, paradigms concerning politeness theories were used to explain marked differences between the request strategies of the test groups. Overall, the results indicated that Russian speakers make a clear distinction between conversational and institutional settings whereas Irish English speakers generally do not. In addition, high levels of social informality were evidenced by the Irish English speakers across settings while Russian speakers tended to enact identity in line with the context.
\end{abstract}

Keywords: Irish English, Russian, Requests, Cross-cultural Pragmatics

\section{Introduction}

Various theories have attempted to provide a taxonomy of universals of pragmatic norms across all languages and cultures. Arguments supporting the prevalence of such universals are predicated on the "extraordinary parallelism in the linguistic minutiae of the utterances with which people choose to express themselves in quite unrelated languages and cultures" (Brown \& Levinson, 1987, p. 60). Politeness theory states that negative face must be attended to in requests since they are face-threatening acts which impede the hearer's freedom (Brown \& Levinson, 1987). However, since the concept of face is complex and dependent on culture (Trosborg, 1995), it leaves the notion of the universality of pragmatic norms open to criticism. 
Wierzbicka $(1985,2003)$ argued that while the concept of negative face is salient in English, it may not be so in other languages. Central to this argument is that the avoidance of the flat imperative is said to reflect fundamental politeness norms (Searle, 1975). However, Wierzbicka (1985) highlights that Polish speakers prefer the imperative whereas interrogative forms are favoured by English speakers in requests, thereby successfully illustrating that negative face is not as strong in Polish as it is in English. Ogiermann (2009) supports this finding having investigated requests in English, German, Polish and Russian and concluded that the use of the imperative for requests increases from West to East. Given these findings, this study aims to provide further insight into cross-cultural pragmatics by comparing requests in Irish English and Russian.

\section{Background}

This section provides a brief overview of some theoretical frameworks and fundamental considerations regarding requests and politeness. Thereafter, the key linguistic and pragmatic characteristics of IrE and Russian are outlined along with a review of studies into the pragmatics of both languages.

\subsection{Requests and Politeness}

Requests are categorised as directives within speech act theory as the speaker attempts to get the hearer to do something (Searle, 1979). There is a scale of optionality which distinguishes orders from requests (Leech, 2014). In formulating a socio-culturally appropriate request, a speaker must consider several points. Firstly, requests are formulated based on sociocultural conditions such as power, social distance and the level of imposition involved (Brown \& Levinson, 1987; Leech, 2014). Secondly, a balance of directness and indirectness is required to maximise the chance of hearer compliance while avoiding causing offence. Finding this balance can cause psychological conflict for the speaker (Forgas, 2001). Thirdly, the degree of appropriateness of a request depends on whether it occurs in a conversational or institutional setting. Generally, language used in the former is informal and flexible while the latter is more formal and more formulaic (Devlin, 2014). Thus, requests are a demanding and challenging speech act to master and can be particularly problematic in cross-cultural communication due to sociopragmatic failure (Thomas, 1983). 
Requests have been studied from the perspectives of politeness and (in)directness. However, indirectness does not equate to politeness and it has been shown that the two are perceived differently in requests (Blum-Kulka, 1987; Marti, 2006). In realizing a request, speakers may employ various politeness strategies to avoid threatening negative face including being conventionally indirect, hedging and minimizing the imposition (Brown \& Levinson, 1987). On the other hand, impoliteness strategies include frightening, ridiculing or belittling to attack the hearer's negative face (Culpeper, 1996). However, inherent impoliteness is distinct from mock impoliteness whereby the function of the former is to exert one's power over the hearer whereas the latter fosters closeness (Culpeper, 1996).

\subsection{Irish English and its Pragmatics}

Irish English (IrE) is the variety of English that is spoken and written in Ireland. While Irish maintains its status as the official language of Ireland as of 2018, Irish language speakers comprise $37 \%$ of the population with only $4 \%$ of them speaking it daily (CSO, 2016). Nevertheless, IrE is differentiated from other varieties of English by the rich influence of the Irish language in terms of lexis and syntax as well as being marked by its distinctive phonetic, phonological and morphological features (Kallen, 2012). Furthermore, IrE is "one of many robust native varieties" which is significantly characterised by its pragmatics (O'Keeffe, 2011, p. 63). This is reflected by the growing wealth of research in this area (see, for example, Barron \& Schneider, 2005; Vaughan \& Clancy, 2011; Amador-Moreno, McCafferty \& Vaughan, 2015). According to O'Keeffe and Adolphs (2008), high levels of indirectness, social informality and a high frequency of taboo language can be observed in IrE discourse. The use of the familiarisers lads, girl, and boy helps to both create and foster high social informality (Murphy \& Farr, 2012). Indirectness has been highlighted as a characteristic of IrE speakers in business negotiations (Martin, 2005). Also, discourse markers and the politeness marker please are high frequency forms in service encounters (Binchy, 2005).

Studies have investigated IrE speech acts such as thanking (Schneider, 2005), offers (O'Keeffe, 2011; Barron, 2017), and refusals (Hickey, 2007). Regarding requests, generally higher levels of indirectness have been found in IrE than English English (Barron, 2003; Martin, 2005). Specifically, Barron (2005) found that IrE speakers favour reference to preparatory conditions for requests in comparison with English English speakers. Connington (2005) also found that 
IrE speakers prefer interrogative structures for requests, offers and instructions. In addition, Connington (2005) found that the use of the imperative for requests in IrE is viewed as impolite in a range of contexts. Negation has been highlighted as a common indirect request strategy in IrE (Scharf \& Mac Mathúna, 1998). However, Barron (2003) generated no instances of negation.

In terms of mitigating and face-saving strategies, hedges represent a salient characteristic of IrE (Farr \& O'Keeffe, 2002; Clancy, 2005). Lexically, Clancy and Vaughan (2012) emphasize the function of 'now' as a hedge in face-threatening acts. Also, Murphy (2015) found a correlation between young people (in their twenties) and 'like' as a hedge but found that 'sure' is more evenly distributed among all ages and genders. In addition, Schneider (2008) found that 'so' precedes requests for information more frequently in IrE than in English English and American English. A salient syntactic feature of IrE is the progressive (O'Keeffe \& Amador-Moreno, 2009; Kirk, 2015). In a corpus-based study, Ní Mhurchú (2018) found that various progressive forms hold a range of pragmatic functions from softening and hedging to intensifying. In a comparative analysis, Barron (2003) concluded that syntactic downgrading was more frequently employed in IrE indirect requests than in German. In offers, IrE speakers use significantly more external modifiers than English English speakers (Barron, 2005). However, internal modifiers are more frequently employed in IrE requests whereas English English speakers prefer external ones (Barron, 2008).

\subsection{Russian and its Pragmatics}

Russian is a highly inflected language and has relatively free word order. Interrogative forms are marked by modals or declaratives in conjunction with fronting and/or rise-fall intonation. Russian has a T-V distinction in which the T-form, the second person singular 'ty', is used when the interlocutor is known to you, in informal situations with friends or family, to someone younger than you or to someone of a lower social status. On the other hand, the V-form, the second person plural ' $v y^{\prime}$, is reserved for use when the interlocutor is unknown to you, in official situations, when one wishes to uphold respect or keep one's self at a distance, to those who are older and to those or of a higher social status (Formanovskaia, 2003 as summarized by DeWaard, 2012). Moreover, the Russian imperative declines in both the T-form and V-form and Benacchio (2002) suggests that the perfective imperative is a negative politeness strategy 
while the imperfective imperative functions as a positive politeness strategy. Offord and Gogolitsyna (2005) outline the sociocultural use of Russian personal names. First names have diminutive forms which can be used among socially close interlocutors or by higher power interlocutors when addressing their lower power interlocutors. The patronymic is reserved for formal contexts, introductions, and/or when the addressee is the older, higher power or more socially distant interlocutor.

In direct contrast with English, requests in Russian are not necessarily viewed as an imposition on personal freedom and, consequently, any potential face-loss associated with noncompliance is minimal (Rathmayr, 1994; Ogiermann, 2009). Thus, the imperative is considered the most appropriate and polite request strategy in Russian for many contexts (Rathmayr, 1994; Berger, 1997; Brehmer, 2000; Betsch, 2003; Larina, 2003; Ogiermann, 2009; Bolden, 2017). According to Mills (1992), requests which refer to preparatory conditions in Russian (e.g. vy mozhete (could you) are considered overly polite and require the hearer to disambiguate that the speaker is realizing a request and, hence, not simply seeking a yes/no response. However, while Ogiermann (2009) did note a higher usage of the imperative for Russian than other languages in her study, most of the Russian responses were nevertheless conventionally indirect. Also, Mills (1992) suggested that Russian and English have antithetical request strategies.

In terms of mitigation, Mills (1992) found that negation is the primary mitigating strategy in Russian. Modality can be used to soften a Russian request in any context (Ogiermann, 2009) and is especially appropriate for formal contexts (Dorodnych, 1995). However, the Russian equivalent of please, pozhaluista, is reserved for use with the imperative (Mills, 1992; Betsch, 2003), especially in high imposition requests where it functions as a modulating device rather than a politeness marker (Bolden, 2017). Furthermore, Russian speakers prefer to use cost minimisers than grounders, focusing on the duration of the request than providing justification for it (Ogiermann, 2009). Also, using address terms may further increase the degree of politeness in Russian requests (Mills, 1992). 


\section{Method}

\subsection{Research Questions}

The following research questions guided the study:

- Do Irish English and Russian differ when realizing requests in conversational and institutional settings and if so, how and why?

- Does the request strategy employed in each setting differ between Irish English and Russian and if so, how and why?

\subsection{Data}

An original ten-question written discourse completion task (WDCT) was used to generate data of 600 responses from a random sample of 30 Russian and 30 IrE speakers. The WDCT allowed the social variables of power, social distance and the level of imposition to be controlled. Five request situations were used for the conversational setting and were adapted to fit institutional equivalents by changing the interlocutor (e.g. mother/boss), the social setting (e.g. street/bank) or the nature of the request (e.g. a re-fill/a specific drink). Contextual information including the relationship between interlocutors was provided. The WDCT was first written in IrE, and then the Russian equivalent was written making appropriate cultural changes, for example regarding patronymic names and currency. Some limitations of the study include the relatively small sample size. Also, possible shortcomings regarding the design of the WDCT include the amount of contextual information provided. For instance, too many details may have prompted the use of a particular request strategy whereas too little information may have elicited shorter responses. Moreover, from the perspective of the analysis, the fact that the researcher is a native IrE speaker and second language Russian speaker must be emphasized.

\subsection{Analytical framework}

The data were analysed using a slightly altered version of Blum-Kulka and Olshtain's coding categories (1984) according to five units of analysis: address terms and greetings, head acts, internal modification, external modification and politeness markers. Then, descriptive 
statistics were used to compare within and across test groups. To illustrate the coding framework, consider the following request situation for quiet in the conversational setting (CS): You are at home trying to study, but the neighbours' children are playing noisily in the hallway outside your apartment. You decide to say something to them. The following examples are from the data.

(1) Hi lads, would you mind being a bit quieter? I'm just trying to study. Thanks.

For the IrE conversational request (1), the address term ( $\mathrm{Hi})$ and greeting (lads) were categorised as informal. The head act (would you mind...) was coded as pure preparatory. Both internal modification (a bit, just) and external modification (I'm just trying to study) were used. A politeness marker was also used (thanks).

For the Russian conversational request (2), the address term was informal (children). The head act was categorised as an elided imperative (quiet). The equivalent of please (pozhaluista) was categorised as a politeness marker. Also, a grounder was used (you are preventing me from work).

$\begin{array}{cclll}\text { (2) Deti } & \text { tishe } & \text { pozhaluista vy meshaete rabotat' } \\ \text { Children } & \text { quiet } & \text { please you prevent to work }\end{array}$

Children, quiet please, you are preventing me from working

The equivalent request for quiet in the institutional setting (IS) was as follows: You are under pressure at work. Your colleagues are chatting very loudly, so you can't concentrate on your work. You decide to say something to them.

(3) Listen, I'm really sorry but I'm flat out here, any chance you could tone it down a bit please?

In the IrE institutional request (3), the participant used an informal attention getter (Listen). The head act was categorised as chance preparatory (any chance you could). This slight modification to the coding was made to distinguish pure preparatory from chance 
preparatory, which was prevalent in the IrE data. Internal modifiers included three different downgraders: an understater (a bit), downtowner (I'm really sorry but...) and hedge (tone it down). A grounder was also included (I'm flat out here). A politeness marker (please) was used, too.

In the Russian institutional request (4), the participant used an informal address term (Colleagues). The head act (you wouldn't) was coded as negation, which was another slight modification. A grounder was used, too (I really need to concentrate).

(4) Kollegi ne mogli by vy razgovarivat' potishe?

Colleagues not able would you to talk more quietly?

Mne ochen' nuzhno skoncentrirovat'sja

I really need to concentrate

Colleagues, you wouldn't be able to talk more quietly? I really need to concentrate?

\section{Results}

Table 1 shows the results of the IrE and Russian (RU) head acts for all situations across settings.

\begin{tabular}{|l|c|c|c|c|c|c|c|c|}
\hline Head act & \multicolumn{2}{|c|}{ IrECS } & \multicolumn{2}{|c|}{ IrEIS } & \multicolumn{2}{c|}{ RUCS } & \multicolumn{2}{c|}{ RUIS } \\
\hline & $\mathbf{n}$ & $\%$ & $\mathbf{n}$ & $\%$ & $\mathbf{n}$ & $\%$ & $\mathbf{n}$ & $\%$ \\
\hline Direct & & & & & & & & \\
\hline Imperative & 12 & 8 & 6 & 4 & 66 & 44 & 26 & 17 \\
\hline Other (e.g. explicit performative) & 1 & .67 & 0 & 0 & 11 & 7.33 & 4 & 2.67 \\
\hline Total direct & $\mathbf{1 3}$ & $\mathbf{8 . 6 7}$ & $\mathbf{6}$ & $\mathbf{4}$ & $\mathbf{7 7}$ & $\mathbf{5 1}$ & $\mathbf{3 0}$ & $\mathbf{1 9 . 6 6}$ \\
\hline & & & & & & & & \\
\hline Conventionally indirect & & & & & & & & \\
\hline Pure preparatory & 74 & 49.33 & 87 & 58 & 24 & 16 & 21 & 14 \\
\hline Chance preparatory & 19 & 12.67 & 17 & 11 & 0 & 0 & 0 & 0 \\
\hline Negation & 12 & 8 & 4 & 3 & 35 & 23 & 44 & 29 \\
\hline Hedge & 12 & 8 & 0 & 0 & 1 & 1 & 2 & 1 \\
\hline Other (e.g. locution derivable) & 15 & 10 & 30 & 20 & 3 & 2 & 44 & 30 \\
\hline
\end{tabular}




\begin{tabular}{|l|c|c|c|c|c|c|c|c|}
\hline Total conventionally indirect & $\mathbf{1 3 2}$ & $\mathbf{8 8}$ & $\mathbf{1 3 8}$ & $\mathbf{9 2}$ & $\mathbf{6 3}$ & $\mathbf{4 2}$ & $\mathbf{1 1 1}$ & $\mathbf{7 4}$ \\
\hline & & & & & & & & \\
\hline Non-conventionally indirect & & & & & & & & \\
\hline Total hinting (mild/strong) & 5 & 3.33 & 6 & 4 & 7 & 5 & 4 & 3 \\
\hline & & & & & & & & \\
\hline Other & & & & & & & & \\
\hline Would not carry out request & $\mathbf{0}$ & $\mathbf{0}$ & $\mathbf{0}$ & $\mathbf{0}$ & $\mathbf{3}$ & $\mathbf{2}$ & $\mathbf{5}$ & $\mathbf{3 . 3 4}$ \\
\hline
\end{tabular}

Table 1: Distribution of Irish English and Russian head acts

Table 2 shows the results of other units of analysis used by both test groups across settings.

\begin{tabular}{|l|c|c|c|c|}
\hline & IrECS & IrEIS & RUCS & RUIS \\
\hline & $\mathbf{n}$ & $\mathbf{n}$ & $\mathbf{n}$ & $\mathbf{n}$ \\
\hline Address terms and greetings & & & & \\
\hline Formal & 19 & 11 & 19 & 51 \\
\hline Informal & 88 & 90 & 59 & 25 \\
\hline & & & & \\
\hline Internal modifiers & & & & \\
\hline Downgrader & 8 & 20 & 8 & 14 \\
\hline Upgrader & 6 & 6 & 4 & 0 \\
\hline Upgrader (taboo language) & 6 & 6 & 0 & 0 \\
\hline & & & & \\
\hline External modifiers & & & & \\
\hline Downgrader & 10 & 13 & 5 & 22 \\
\hline Upgrader (grounder) & 40 & 62 & 28 & 48 \\
\hline & & & & \\
\hline Politeness markers & 44 & 78 & 44 & 54 \\
\hline
\end{tabular}

Table 2: Distribution of other units of analysis

\section{Discussion}

For the IrE requests, conventionally indirect head acts were the overwhelming preference (see Table 2) with pure preparatory the most prevalent, which was employed in $49.33 \%$ of requests in IrECS and 58\% in IrEIS. Direct requests were relatively infrequent but were more 
frequent in the conversational setting than the institutional and were heavily mitigated when employed. Hinting was also relatively infrequent. Thus, the same head acts were available for IrE requests across settings and high levels of indirectness were evident.

The employment of address terms and greetings, internal and external modifications and politeness markers was shown to be predicated on social variables. As evident in Table 2 , the IrE participants showed a strong preference for informal address terms and greetings in both settings. Conversely, formal greetings were reserved for use mostly with socially distant interlocutors in conversational settings. Grounders were the primary means of modification across settings. While internal upgraders and taboo language remained unchanged across settings, all other modifiers and politeness markers increased in the institutional setting. These results indicate that social variables influence the use of request modifications, but not necessarily head acts, for IrE speakers.

The findings corroborate Barron (2005) regarding the preference of IrE speakers for pure preparatory head acts. In contrast with Barron (2003), negation was used by the IrE participants in both settings ( $8 \%$ for IrECS and 3\% for IrEIS) and was most frequently employed in high imposition requests to socially distant interlocutors. The infrequent and heavily mitigated use of the imperative supports Connington (2005) in generalising that it is considered an impolite request strategy in IrE in a range of contexts. The preference for grounders (Barron, 2005) can also be corroborated by the results.

The increasing use of modifiers in the institutional setting can be explained in part by the concept of negative face as the IrE speakers sought to further minimize the imposition. Hence, the results suggest that the concept of negative face is very strong in Irish culture, perhaps particularly so in institutional settings. Mock impoliteness (Culpeper, 1996) was vital to explaining some IrE request strategies among socially close interlocutors. Examples included 'grown-ups working here' requesting quiet in IrEIS as well as 'no point in leaving a drop in the bottle...I'Il finish it off for you!' as a request for a refill in IrECS. Another noteworthy point is that taboo language was distributed evenly across settings, indicating that IrE speakers may not discriminate in its use by context. Furthermore, various functions of taboo language were evident. For instance, inherent impoliteness was evident in the example 'fuck off and play 
somewhere else' as the speaker sought to exert his power over children requesting quiet in IrECS. Also, taboo language was employed to increase the emotive force (Murphy, 2009) and perhaps gain hearer compliance in examples such as 'Mom, open the fuckin' window' in IrECS and 'Oh my God, you lot are wrecking my head, I can get feck all done...' in IrEIS. Thus, the IrE use of taboo language may suggest a preference for informal language regardless of context.

Overall, the results support O'Keeffe and Adolphs' (2008) suggestion that high social informality is characteristic of IrE. This was evidenced across settings through informal address terms and greetings, the employment of mock impoliteness and taboo language. This blurred lines between the distinctive, antithetical features of conversational and institutional settings (Devlin, 2014). Therefore, there may be a suggestion that the personal identity of an IrE speaker supersedes his/her institutional identity because of high social informality, high levels of indirectness and mock impoliteness characteristic of, and embedded in, Irish culture.

Regarding the Russian requests, there was marginal preference for direct strategies in the conversational setting (51\%) while a considerable number were also employed in the institutional (19.66\%). The imperative T-form was shown to be most appropriate for low imposition requests to socially close interlocutors. However, the results overall do not support Rathmayr (1994), Berger (1997), Brehmer (2000), Betsch (2003) and Larina (2003) in presupposing that the imperative is the most appropriate request strategy in Russian as there were no instances of its use in high imposition requests to socially distant interlocutors. The results indicated that negation is most appropriate in that context. Conventionally indirect strategies were preferred in the institutional setting with negation being the most prevalent head act (see Table 1). There were relatively few uses of hinting. When participants indicated that they would not make a request, they cited social distance as the reason. In general, the Russian participants demonstrated an inverse relationship between social distance and directness, that is, the lower the social distance, the higher the directness. Conversely, the Russian participants favoured indirect head acts with socially distant interlocutors and in institutional settings. Hence, social variables influenced the choice of Russian head acts.

While the same strategies are available for Russian requests across settings, it is its execution which marks its appropriateness. The T-V distinction was shown to be relevant in the 
employment of imperatives whereby most imperatives in the conversational setting were Tform but were V-form in the institutional. Additionally, the marked increase in the use of indirect head acts (see Table 1), formal address terms and greetings, internal and external modification (apart from internal upgraders) and politeness markers in the institutional setting (see Table 2) indicates a correlation between context and the degree of formality, (in)directness, and mitigation. The preference for negation in both settings ( $23 \%$ in RUCS and $29 \%$ in RUIS) reiterates that it is the preferred mitigating strategy in Russian (Mills, 1992). However, the results refute the claim by Mills (1992) and Betsch (2003) that pozhaluista is used only with imperative requests as it appeared with negation, pure preparatory and locution derivable head acts, too. Additionally, the results cannot support the notion that a form of address elevates the politeness of a Russian request (Mills, 1992). However, there was a clear indication that informal address terms and greetings are reserved for conversational settings (or socially close interlocutors) and formal address terms are reserved for the institutional (or socially distant/higher power interlocutors).

The concept of negative face was evident in requests with socially distant or higher power interlocutors and for requests involving a high level of imposition. This was indexed via indirectness or V-form imperatives as well as formal address terms and greetings. However, the high value placed on directness (Rathmayr, 1994) was also apparent via the use of the imperative across settings (44\% in RUCS and $17 \%$ in RUIS). Also, adherence to sociocultural norms pertaining to social distance was evidenced by increased indirectness in the institutional setting. Additionally, there were no instances of taboo language or mock impoliteness in the Russian data. However, while inherent impoliteness was not noted in RUIS, it was for the request for quiet in RUCS. Examples included 'khvatit shumet' tam' (stop making noise here) and 'ugomonites'!' (settle down!). The avoidance of taboo language and mock impoliteness as well as inherent impoliteness in the institutional setting may reflect the value placed on frankness and/or adherence to Russian sociolinguistic norms.

Overall, the marked differences in the Russian requests indicate that Russian speakers make a clear distinction between conversational and institutional settings and that attending to negative face is more apparent in the latter. This was further illuminated by the T-V distinction and address terms that indicate the relationship between interlocutors. Thus, it appears that 
Russian speakers linguistically enact identity in accordance with the setting and that the identity of a Russian speaker is contextually defined before being enacted.

In terms of overall comparison, the Russian participants used formal address terms and greetings markedly more in institutional settings while the IrE participants used more formal address terms and greetings in the conversational (mostly among socially distant interlocutors). Regarding head acts, the results demonstrate the preference of IrE speakers for pure preparatory head acts across settings, supporting Barron (2005). Furthermore, the Russian results demonstrate a slight preference for direct strategies in the conversational setting but a preference for conventionally indirect strategies in institutional settings. Overall, the Russian data generated more conventionally indirect strategies than direct strategies, in line with Ogiermann (2009). Hence, context is more important in the choice of head act for Russian speakers than for IrE speakers, who tend to use indirect strategies in many contexts. The concept of negative face was shown to be very strong for the IrE participants in both settings whereas it was more evident in the institutional setting for the Russian participants. Thus, as negative face was more evident in the IrE data, this supports Wierzbicka's (1985) argument that the concept of face is heavily embedded in English. However, the results cannot support Mills (1992) in purporting that English and Russian use antithetical head acts because both test groups shared a range of conventionally indirect head acts.

Regarding modification, both groups showed a preference for grounders in both settings. The preference for grounders among the Russian participants contrasts with Ogiermann (2009) and may be due to the design of the WDCT which provided a reason for all requests. The use of modifications by the IrE participants was predicated on social variables as their use increased in institutional settings. However, it is unclear from the results whether the choice of head act was predicated on the same variables for the IrE participants as most requests were indirect in both settings. Conversely, social variables were shown to influence the choice of head act as well as the use of internal and external modifications for the Russian participants. Concerning politeness markers, both test groups used more in the institutional setting. It appears that politeness markers are relatively highly conventionalized in IrE institutional settings. Given that pozhaluista was mostly used to mark imperative requests, 
this provides some evidence that it serves to increase the illocutionary force of a request (Bolden, 2017).

Additionally, since the WDCT did not elicit any examples of taboo language or mock impoliteness in the Russian data but was evident in both settings in the IrE data, this further indicates that IrE speakers prefer, and perhaps place a higher value on, highly informal language use as a means of saving negative face. However, inherent impoliteness was evidenced by both test groups via direct strategies and indicates some evidence of the universality of pragmatic norms regarding impoliteness.

\section{Conclusions, Limitations and Further Study}

This study researched if and how IrE and Russian differ in realizing requests in conversational and institutional settings and attempted to explain the differences. Overall, the general hypothesis that Russian speakers are more direct than IrE speakers held true across settings. High levels of social informality among the IrE participants indicated an enactment of personal identity regardless of setting. On the other hand, the results indicated a distinct correlation in the use of formal language and institutional settings for Russian speakers. Hence, it can be generally concluded that Russian speakers enact institutional identities whereas IrE speakers do not. As the strategies for polite requests between the groups differed in many ways, the results have implications for cross-cultural communication between IrE and Russian speakers.

The results have corroborated and refuted some findings of previous research in IrE and Russian pragmatics. However, more research into requests is required to provide further validity to these findings. Also, more research into other speech acts such as apologies and offers is required to gain a broader picture of the pragmalinguistic and sociopragmatic commonalities and differences of the two languages and cultures. Other areas for future research include language and identity studies of IrE and Russian speakers as well as investigating perceptions of the use of please and pozhaluista as marking the illocutionary force of a request. 


\section{References}

Amador-Moreno, C.P., McCafferty, K., \& Vaughan, E. (Eds.). (2015). Pragmatic markers in Irish English (Vol. 258). Amsterdam/Philadelphia: John Benjamins.

Barron, A. (2003). Acquisition in interlanguage pragmatics: Learning how to do things with words in a study abroad context. Amsterdam/Philadelphia: John

Benjamins.

Barron, A. (2005). Offering in Ireland and England. In A. Barron and K.P Schneider (Eds.), The pragmatics of Irish English. Berlin/New York: Mouton de Gruyter, pp.141-177.

Barron, A. \& Schneider, K.P. (2005). The pragmatics of Irish English. Berlin/New York: Mouton de Gruyter.

Barron, A. (2008). The structure of requests in Irish English and English English. In A. Barron and K.P. Schneider (Eds.), Variational pragmatics. Amsterdam/Philadelphia: John Benjamins, pp.35-68

Barron, A. (2017). The speech act of 'offers' in Irish English. World Englishes, 36(2), 224-238.

Benacchio, R. (2002). Konkurencija vidov, vezhlivost' i jetiket $v$ russkom imperative. [Competition of types, politeness and etiquette in the Russian imperative] Russian Linguistics (26), 149178.

Berger, T. (1997). Alte und neue Formen der Höflichkeit im Russischen - einekorpusbasierte Untersuchung höflicher Direktiva und Kommissiva. [Old and new forms of politeness in Russian - a corpus-based investigation of polite directives and commissives] In P.

Kosta and E. Mann (Eds.), Slavistische Linguistik 1996. Munich: Otto Sagner, pp.9-29.

Betsch, M. (2003). Questions as indirect requests in Russian and Czech. In K.M. Jaszczolt and K. Turner (Eds.), Meaning through Language Contrast II. Philadelphia: John Benjamins, pp.277-290.

Binchy, J. (2005). Three forty two so please: Politeness for sale in southern-Irish service encounters. In A. Barron and K.P. Schneider (Eds.), The pragmatics of Irish English. Berlin/New York: De Gruyter Mouton, pp. 313-335.

Blum-Kulka, S. \& Olshtain, E. (1984). Requests and apologies: A cross-cultural study of speech act realization patterns (CCSARP). Applied Linguistics, 5(3).

Blum-Kulka, S. (1987). Indirectness and politeness in requests: Same or different? Journal of Pragmatics, 11, 131-146.

Bolden, G. (2017). Requests for here-and-now actions in Russian conversation. In M-L. Sorjonen, L. Raevaara and E. Couper-Kuhlen (Eds.), Imperative Turns at Talk: The design of directives in action, Studies in Language and Social Interaction, Vol. 30, Amsterdam/Philadelphia: John Benjamins, pp.175-214.

Brehmer, B. (2000). Höfliche Imperative im Russischen. [Polite imperative in Russian]. In, K. Böttger, M. Giger, and B. Wiemer (Eds.), Beiträge der Europäischen Slavistischen Linguistik (POLYSLAV) 3, Munich: Otto Sagner, pp.47-57.

Brown, P. \& Levinson, S. (1987). Politeness. Some universals in language usage. Cambridge: Cambridge University Press.

Central Statistics Office. (2016). Census 2016 summary results - Part 1, Chapter 7, The Irish Language. Retrieved from https://www.cso.ie/en/media/csoie/releasespublications/documents/population/201 7/7._The_Irish_language.pdf

Clancy, B. (2005). You're fat. You'll eat them all. Politeness strategies in family discourse. In A. Barron and K.P. Schneider (Eds.), The pragmatics of Irish English. Berlin/New York: De Gruyter Mouton, pp.164-177 
Clancy, B. \& Vaughan, E. (2012). It's lunacy now" A corpus-based pragmatic analysis of the use of 'now'. In B. Migge and M. Ní Chiosáin (Eds.), New perspectives on Irish English. Amsterdam/Philadelphia: John Benjamins. pp.225-246.

Connington, S. (2005). An examination of the relationship between Anglo-Saxon cultural ideology and the pragmatic conventions of Irish English use with reference to Wierzbicka's (2003) analysis. M.A. thesis. University of Leicester.

Culpepper, J. (1996). Toward an anatomy of impoliteness. Journal of Pragmatics, 5, 349-367.

DeWaard, L. (2012). Learner perceptions of formal and informal pronouns in Russian. The Modern Language Journal, 96(3), 400-418.

Devlin, A.M. (2014). The impact of study abroad on the acquisition of sociopragmatic variation patterns: The case of non-native speaker English teachers. Bern: Peter Lang Publishers.

Dorodnych, A. (1995). A study of requests in English, Russian and Ukrainian. Papers and studies in contrastive linguistics, 30, 55-63.

Farr, F. \& O'Keeffe, A. (2002). Would as a hedging device in an Irish context: An intra-varietal comparison of institutionalised spoken interaction. In R. Reppen, S. Fitzmaurice and D. Biber (Eds.), Using corpora to explore linguistic variation. Amsterdam: John Benjamins, pp.25-48.

Forgas, J.P. (2001). Affective Intelligence: The Role of Affect in Social Thinking and Behaviour. In J. Ciarrochi, J.P. Forgas and J.D. Mayer. (Eds.). Emotional intelligence in everyday life: A scientific inquiry. New York \& Hove: Psychology Press, pp.46-66. Formanovskaia, N. (2003). Recevoe obshchenie. [Spoken interaction]. Moskva: Ruskii lazyk

Hickey, R. (2007). Irish English: History and present-day forms. Cambridge: Cambridge University Press.

Kallen, J. (2012). The English Language in Ireland: An Introduction. International Journal of Language, Translation and Intercultural Communication, 1(2), 25-41.

Kirk, J. (2015). The progressive in Irish English. In P. Collins (Ed.), Grammatical change in English world-wide, Amsterdam/Philadelphia: John Benjamins, pp.87-118.

Larina, T.V. (2003). Kategoriia Vezhlivosti v Anglijskoi i Russkoi Kommunikativnykh Kulturakh. [The Category of Politeness in English and Russian Communicative Cultures]. Moscow: Izdatelstvo Rossiiskogo Universiteta Druzhby Narodov.

Leech, G. (2014). The pragmatics of politeness. Oxford: Oxford University Press.

Marti, L. (2006). Indirectness and politeness in Turkish-German bilingual and Turkish monolingual requests. Journal of Pragmatics 38(11), 1836-1869.

Martin, G. (2005). Indirectness in Irish-English business negotiation: A legacy of colonialism. In A. Barron and K.P. Schneider (Eds.), The pragmatics of Irish English, Berlin/New York: De Gruyter Mouton, pp. 235-68.

Mills, M.H. (1992). Conventionalized politeness in Russian requests: A pragmatic view of indirectness. Russian Linguistics, 16(1), 65-78.

Murphy, B. (2009). "She "s a f**king ticket": The pragmatics of $f^{* *} k$ in Irish English - an age and gender perspective. Corpora, 4 (1), pp. 85-106.

Murphy, B. (2015). A corpus-based investigation of pragmatic markers and sociolinguistic variation in Irish English. In C.P. Amador-Moreno, K.

McCafferty and E. Vaughan (Eds.), Pragmatic Markers in Irish English. Amsterdam/Philadelphia: John Benjamins. pp.65-88 
Murphy, B. \& Farr, F. (2012). "I'm fine girl, and how are you?" The use of vocatives in spoken Irish English. New Perspectives on Irish English, 203.

Ní Mhurchú, A.N. (2018). What's Left to Say About Irish English Progressives? "I’m Not Going Having Any Conversation with You". Corpus Pragmatics, 2(3), 289-311.

Offord, D. \& Gogolitsyna, N. (2005). Using Russian: A guide to contemporary usage, $2^{\text {nd }}$ edition. Cambridge: Cambridge University Press.

Ogiermann, E. (2009). Politeness and in-directness across cultures: A comparison of English, German, Polish and Russian requests. Journal of Politeness Research. Language, Behaviour, Culture, 5(2), 189-216.

O'Keeffe, A. \& Adolphs, S. (2008). Using a corpus to look at variational pragmatics: Response tokens in British and Irish discourse. In A. Barron and K.P. Schneider (Eds.), Variational pragmatics. Amsterdam: John Benjamins, pp. 69-98.

O'Keeffe, A. \& Amador-Moreno, C.P. (2009). The pragmatics of the be+ after+ V-ing construction in Irish English. Intercultural Pragmatics, 6(4), 517-534.

O'Keeffe, A. (2011). Teaching and Irish English: Irish English is widely understood as a robust native variety by Irish English language teachers. English Today, 27(2), 58-64.

Rathmayr, R. (1994). Pragmatische und sprachlich konzeptualisierte Charakteristika russischer direktiver Sprechakte. [Pragmatic and linguistically conceptualized characteristics of Russian directive speech acts]. In H.R. Mehling (Ed.), Slavistische Linguistik 1993, Munich: Otto Sagner, pp. 251-277.

Scharf, W. \& Mac Mathúna, S. (1998). Cultural values and Irish economic performance. In S. Niemeier, C.P. Campbell, and R. Divren (Eds.), The cultural context in business communication, Amsterdam/Philadelphia: John Benjamins, pp.145-164.

Schneider, K. (2005). 'No problem, you're welcome, anytime': Responding to thanks in Ireland, England, and the U.S.A. In A. Barron and K. Schneider (Eds.), The Pragmatics of Irish English. Berlin: Mouton de Gruyter, pp.101-139.

Schneider, K. (2008). Small talk in English, Ireland and the USA. In K. Schneider and A. Barron (Eds.), Variational Pragmatics. Amsterdam/Philadelphia: John Benjamins, pp.99-140

Searle, J. (1975). Indirect speech acts. In P. Cole and J.L. Morgan (Eds.), Syntax and Semantics, (Vol. 3), Speech Acts, New York: Academic Press, pp.59-82.

Searle, J. (1979). Expression and meaning: studies in the theory of speech acts. Cambridge: Cambridge University Press.

Thomas, J. (1983). Cross-cultural pragmatic failure, Applied Linguistics 4(2), 91-112.

Trosborg, A. (1995). Interlanguage Pragmatics. Berlin: Mouton de Gruyter.

Vaughan, E. \& Clancy, B. (2011). The pragmatics of Irish English: The use of English in Ireland shows specific features which contribute to its unique profile. English Today, 27(2), 4752.

Wierzbicka, A. (1985). Different cultures, different languages, different speech acts. Polish vs. English. Journal of Pragmatics, 9, 145-178.

Wierzbicka, A. (2003). Cross-cultural pragmatics. The semantics of human interaction. Second edition. Berlin/New York: Mouton de Gruyter. 